\title{
Non Invasive Physical Regenerative Therapies: Laser therapy, Mechanism of Action and Results
}

\author{
W. Leonardo Guiloff', Ondrej Prouza ${ }^{2}$, Dragana Žarković
}

\section{Abstract}

Low-level laser therapy (LLLT) and high-intensity laser therapy (HILT) have emerged as a therapeutic alternative suitable for a wide range of medical conditions. The main advantage of high-intensity laser over LLLT is its ability to deliver a much higher dose in a shorter time while achieving deeper penetration into the affected tissue and producing a thermal effect. Although HILT, provides very satisfactory clinical results, more clinical research is require to justify its massive use.

Keywords: Low-level laser therapy, High-level laser therapy, Biostimulation, Phototherapy

\section{Introduction}

Mechanotherapy [1] by means of pressure waves, such as focused shockwaves and radial waves, has provided a therapeutic tool capable of giving solutions in chronic musculoskeletal conditions in which previously the only alternative was surgery [2]. Focused shockwaves trigger a biological response that includes angiogenesis and vasculogenesis, in addition to lymphangiogenesis [3]. However, in cases of acute inflammation with bursitis or synovitis, the application of this type of physical energy can increase pain. Low-level laser therapy (LLLT) and high-intensity laser therapy (HILT) have emerged as an alternative in these cases.

Laser light is characterized by being coherent, polarized, and monochromatic electromagnetic waves $[4,5]$ that can be used in medicine for both invasive and noninvasive purposes. The efficacy of laser therapy is strongly related to photon propagation and distribution speed in irradiated tissues affected by their wavelength. The healing effects of laser light therapy on the human body have been known since the 60's, producing biostimulation and pain relief. Since then, laser therapy has gained popularity as it is a painless and non invasive modality suitable for a wide range of medical conditions $[6,7,8,9,10,11,12,13$, $14,15,16,17,18,19,20,21,22,23,24,25,26$, $27,28,29,30,31,32,33,34]$.

The purpose of this review is to provide an overview about the history, mechanism of action, and indications of laser in the skin and musculoskeletal pathology.

History and Development of Laser Technology

Although Albert Einstein predicted stimulated electromagnetic radiation in 1917 in his article

“Zur Quantentheorie der Strahlung” [35], it took more than four decades for different scientists to come up with theories on how to intensify light in the visible spectrum and in the adjacent infrared wavelength areas using stimulated emission.

The theoretical principles to develop laser devices were defined by Nikolaj G. Basov and Alexandra M. Prokhorov in the Soviet Union in 1955 [36], followed by Charles Townes [37] and Arthur Schawlow [38] in the USA, in 1957. Both American researchers received the Nobel Prize for their studies in quantum physics in 1964.
After many patent disputes between various researchers, Gordon Gould is considered the official inventor and author of the acronym LASER which stands for Light Amplification by Stimulated Emission of Radiation, introduced in 1959 [4].

Despite the official story, many authors consider Theodore Maiman the true inventor of laser. He was the first to create a functional ruby laser in $1960[1,5,39]$. Later, laser devices were built using various active agents that generate coherent electromagnetic radiation. The most frequently used are alkali metal vapors and other gases such as $\mathrm{He}, \mathrm{Ne}, \mathrm{Ar}, \mathrm{CO}_{2}$. These active agents have been successfully adapted to surgery, dermatology, and ophthalmology. New technological solutions allowed the development of significantly cheaper and smaller semiconductor diode lasers, with a wider spectrum of wavelengths, that gave way to a wider clinical use in different medical areas, including physical medicine and rehabilitation (PMR).

In the late 90's, high-intensity laser, or class 4 laser, expanded into the field of PMR and sports medicine. Such technology allowed to generate energy levels of $10 \mathrm{~W}$ and more, achieving a stronger biostimulation [40].

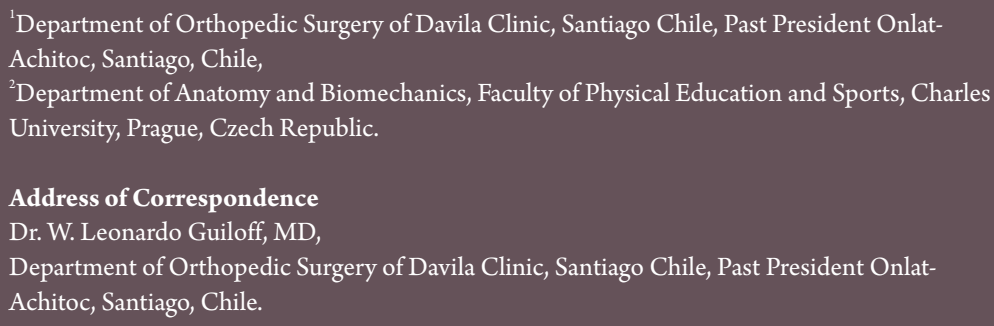

Submitted Date: 7 August 2021, Review Date: 9 Octoer 2021, Accepted Date: 12 November 2021 \& Published: 31 December 2021

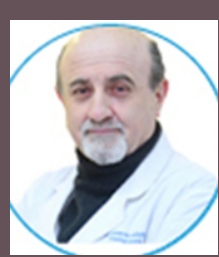

Dr. W. Leonardo Guiloff
Dr. Ondrej Prouza Dr. Dragana Žarković

(C) 2021 by Journal of Regenerative Science | Available on www.jrsonweb.com | DOI:10.13107/jrs.2021.v01.i01.013

This is an open access journal, and articles are distributed under the terms of the Creative Commons Attribution-NonCommercial-ShareAlike 4.0 License (https://creativecommons.org/licenses/by-nc-sa/4.0/), which allows others to remix, tweak, and build upon the work non-commercially, as long as appropriate credit is given and the new creations are licensed under the identical terms. 


\section{Migration with High Energy Laser}

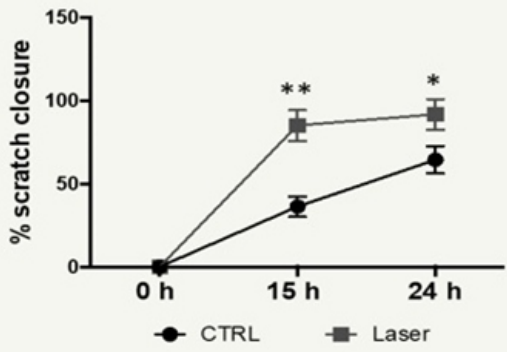

$\mathrm{n}=4$; data presented as mean $+/-\mathrm{SD}$

Increased migration of mesenchymal stem cells after treatment with laser;

Increased secretion of anti-inflammatory molecules after Laser treatment

- Pro-inflammatory environment simulated with LPS $24 \mathrm{~h}$ before Laser treatment

- Supernatant conditioned for $24 \mathrm{~h}$ after Laser treatment

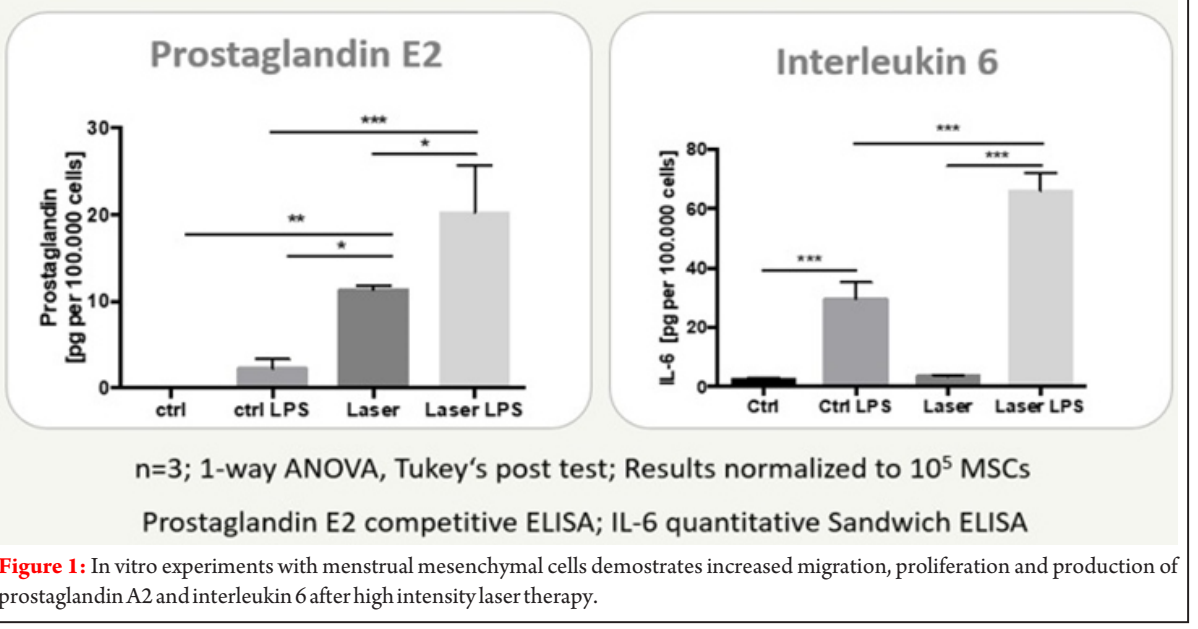

The main advantage of high-intensity lasers over lower intensity lasers is its ability to deliver high therapeutic doses $\left(\mathrm{J} / \mathrm{cm}^{2}\right)$ in a significantly shorter period of time due to its high power $(\mathrm{W})$. The maximum therapeutic dose in LLLT is still debated, however, it generally does not exceed $16 \mathrm{~J} / \mathrm{cm} 2$, but in high-intensity laser the common dose is generally around $80-120 \mathrm{~J} / \mathrm{cm}^{2}$, which determines higher clinical effectiveness.

Other advantages of HILT over LLLT, is that at wavelengths above $1000 \mathrm{~nm}$, it can penetrate deeper improving clinical effects. LLLT is unable to penetrate deep into the joints and large muscle groups and to release enough energy to achieve a therapeutic effect. HILT generates immediate analgesic and muscle relaxant effects on pulsed emissions and has thermal effect when applied in continuous emission. This is valuable for treating acné [41], scars [42, 43, 44, 45, 46] and superficial muscles [47]. There are two

\section{Proliferation WST-1 assay}

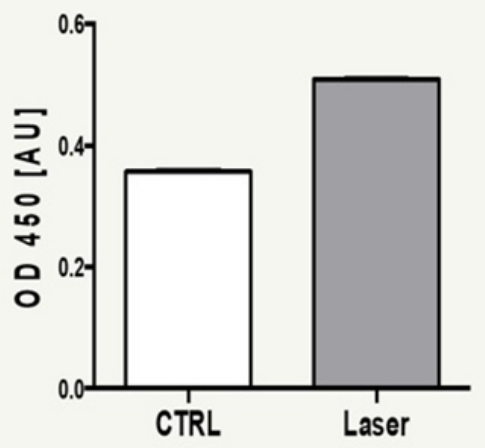

$\mathrm{n}=3$; data presented as mean +/- SD

compromising clinical efficacy. Laser therapy, for years, was carried out and controlled in a conventional way, that is, the applicator was handled by an operator on the site to be treated. Despite all preventive and safety measures, a human operator will never be able to constantly perform the same movement over the affected area, therefore, the power distribution could differ. For this reason, automated laser applicators were designed, they can perform replicable movements on the affected area to guarantee a homogeneous distribution of laser energy, as shown by Baack $[48,49]$.

\section{Laser Radiation Absorption}

Human skin represents a biological, mechanical, and chemical barrier. It also gives optical protection to laser light. The reflection of the laser light represents the loss of electromagnetic radiation caused by the difference in refraction. Previous research confirms that wavelengths in the nearinfrared (NIR) regions (above $1000 \mathrm{~nm}$ ) lead to less energy loss. Absorption means transferring energy to the target tissue and results in an energy loss defined by the absorption coefficient. The main laser light absorbers in human tissues are melanin, water, and hemoglobin.

The absorption of light increases with the concentration of melanin in the skin. The peak of melanin absorption is between 300 and $400 \mathrm{~nm}$ in NIR regions and decreases with longer wavelengths. At wavelengths $>1100 \mathrm{~nm}$, melanin absorption is almost negligible [48]. Water is a weak absorption chromophore in the visible wavelength spectrum increasing absorption within the NIR and infrared regions. Studies showed that there is almost no absorption below 800 $\mathrm{nm}$, while the highest absorption was shown at wavelengths within the range of $900 / 1150$ $\mathrm{nm}[50]$.

Hemoglobin is the main blood component responsible for absorbing and scattering radiation. The absorption spectra depend on the oxygen rich or oxygen poor hemoglobin state. The main difference between these two states occurs at wavelengths $>950 \mathrm{~nm}$. According to Tseng et al. [51], the absorption of deoxyhemoglobin decreases continuously from the wavelength of $900 \mathrm{~nm}$. The reflection is negligible for the wavelength of $1064 \mathrm{~nm}$. The absorption coefficient of melanin decreases from $690 \mathrm{~nm}$ to $1064 \mathrm{~nm}$ 
and reduces energy loss in the skin $[48,52$, 53].

\section{Biological Effects of Laser Radiation}

Biostimulation is considered to be the main laser biological effect. It was first described in 1967 by Endre Mester, a professor at Semmelweis University in Budapest, who used experimental radiation on a group of mice to verify whether laser radiation can produce malignant tissue [54]. However, this effect was not demonstrated, and mice that were exposed to experimental low-intensity laser radiation, within the red spectrum of light radiation, showed significantly faster regeneration of their shaved skin compared to the non-exposed group. Mester also applied laser on open skin lesions and demonstrated the healing effects of laser radiation through a series of histological and immunological tests [54]. The term laser biostimulation [54] was later generalized by some of the authors as "laser bio-modulation," for a better specification of the stimulation to which other effects such as suppression of inflammation and its powerful analgesic effect are added.

Specific parts of the cellular mitochondrial chains can absorb the specific wavelength of laser radiation and release signaling molecules (NO, cytokines, growth factors). This leads to increased adenosine triphosphate formation and cell metabolism, resulting in tissue regeneration and healing. The biostimulation effect is linked to studies indicating that laser radiation increases fibroblast activity, collagen synthesis, and angiogenesis due to the proliferation of endothelial cells in affected tissues [52, 53, $55,56,57,58,59]$.

Peat et al. [60] demostrated in the equine bone marrow that HILT has an antiinflammatory action by inhibiting the synthesis of proinflammatory cytokines at the transcriptional level. We had a similar result in conjunction with the biomedical engineer Dr. Christina Schuh, at the Universidad del Desarrollo, Santiago de Chile. Mesenchymal cells treated with 1064 $\mathrm{nm}$ laser, migrated, proliferated, and produced Prostaglandin E2 and Interleukin 6 in much greater quantity than the control group (Fig. 1). The effect was greater in cells previously seeded with a cellular irritant lipopolysaccharide, equivalent to those found in the cell membrane of Gram-negative bacteria. Bjordal et al. demonstrated that LLLTs reduced microdialysis measured PGE2 levels in LLLT activated Achilles tendonitis [61]. Laser therapy can also be used to reduce edema [16].

Pain relief is achieved by stimulation of the A, $\delta$, and $\mathrm{C}$ nerve fibers and the secretion of endogenous opioids alpha and betaendorphins that bind to opiate receptors of the nociceptive system. This was demonstrated by Walker et al. [62] that described the elimination of 5 hydroxy indoleacetic acid in urine after local irradiation with LLLT in patients suffering from chronic pain. Laser therapy can directly affect the peripheral nervous system.

Due to the biological background of the aforementioned effects, laser appears clinically effective in acute and chronic neck and low back pain $[11,12,13,14,15,23,63]$, and in degenerative joint conditions such as osteoarthritis of the knee $[20,21,25,28,30$, $33]$ and rheumatoid arthritis [27, 33, 64]. A systematic review by Wyszynska and BalBochenska [33], analyzed the literature on the use of high-energy laser therapy in knee osteoarthritis and concluded that HILT seems to be efficient in reducing pain and for providing functional improvements. We were able to replicate these results in a treatment protocol developed by our team [65].

Laser therapy is also useful in other disorders such as temporomandibular degenerative processes [26], shoulder impingement síndrome [32], tendinopathies $[17,18,66]$, fibromyalgia [67], peripheral nerve disorders $[12,68,69]$, and in the healing of wounds $[24,41,42,43,44,45,70]$. Laser therapy has promising results for the treatment of cold sores [71] and onychomycosis [72,73].

\section{Conclusión}

Laser therapy is a clinically proven, noninvasive modality suitable for a wide range of medical conditions. LLLT has been in use for over 50 years. Despite the limits of LLLT, therapy may be suitable for superficial and dermatological problems.

The main advantage of high-intensity laser over LLLT is its ability to deliver a much higher dose in a shorter time while achieving deeper penetration into the affected tissue and producing a thermal effect. Although HILT, provides very satisfactory clinical results, more clinical research is require to justify its massive use.

Declaration of patient consent: The authors certify that they have obtained all appropriate patient consent forms. In the form, the patient has given his consent for his images and other clinical information to be reported in the Journal. The patient understands that his name and initials will not be published, and due efforts will be made to conceal his identity, but anonymity cannot be guaranteed.

Conflicts of Interest: Nil. Source of Support: None.

\section{References}

1. Huang C, Holfeld J, Schaden W, Orgill D, Ogawa R. Mechanotherapy: Revisiting physical therapy and recruiting mechanobiology for a new era in medicine. Trends Mol Med 2013;19:555-64.

2. Moya D, Ramón S, Schaden W, Wang CJ, Guiloff L, Cheng JH. The role of extracorporeal shockwave treatment in musculoskeletal disorders. J Bone Joint Surg Am 2018;100:251-63.

3. Brañes J, Contreras HR, Cabello P, Antonic V, Guiloff LJ, Brañes M. Shoulder rotator cuff responses to extracorporeal shockwave therapy: Morphological and immunohistochemical analysis. Shoulder Elbow 2012;4:163-8.

4. Taylor N. Laser: The Inventor, the Nobel Laureate, and the Thirty Year

\section{Patent war. New York: Nick Taylor Simon Schuster; 2000}

5. Myers R, Dixon R. Who invented the laser: An analysis of the early patents. In: Historical Studies in the Physical and Biological Sciences. Vol. 34. California: University of California Press; 2003. p. 115-49.

6. Mester E. Risultati clinici di stimolazione laser e studi sperimentali circa il meccanismo di azione [Clinical results of laser stimulation and experimental studies on its mechanism of action]. Minerv Med. 1981;72:2195-9.

7. Huang YY, Chen AC, Carroll JD, Hamblin MR. Biphasic dose response in low level light therapy. Dose Response 2009;7:358-83. 
8. Wickenheisser VA, Zywot EM, Rabjohns EM, Lee HH, Lawrence DS, Tarrant TK. Laser light therapy in inflammatory, musculoskeletal, and autoimmune disease. Curr Allergy Asthma Rep 2019;19:37.

9. Cotler HB, Chow RT, Hamblin MR, Carroll J. The use of low level laser therapy (LLLT) for musculoskeletal pain. MOJ Orthop Rheumatol 2015;2:00068.

10. Clijsen R, Brunner A, Barbero M, Clarys P, Taeymans J. Effects of lowlevel laser therapy on pain in patients with musculoskeletal disorders: $A$ systematic review and meta-analysis. Eur J Phys Rehabil Med 2017;53:603-10.

11. Konstantinovic LM, Kanjuh ZM, Milovanovic AN, Cutovic MR, Djurovic AG, Savic VG, et al. Acute low back pain with radiculopathy: A double-blind, randomized, placebo-controlled study. Photomed Laser Surg 2010;28:553-60.

12. Konstantinovic LM, Cutovic MR, Milovanovic AN, Jovic SJ, Dragin AS, Letic MD, et al. Low-level laser therapy for acute neck pain with radiculopathy: A double-blind placebo-controlled randomized study. Pain Med 2010;11:1169-78.

13. Chow RT, Johnson MI, Lopes-Martins RA, Bjordal JM. Efficacy of lowlevel laser therapy in the management of neck pain: A systematic review and meta-analysis of randomised placebo or active-treatment controlled trials. Lancet 2009;374:1897-908.

14. Djavid GE, Mehrdad R, Ghasemi M, Hasan-Zadeh H, SotoodehManesh A, Pouryaghoub G. In chronic low back pain, low level laser therapy combined with exercise is more beneficial than exercise alone in the long term: A randomised trial. Aust J Physiother 2007;53:155-60.

15. Momenzadeh S, Kiabi FH, Moradkhani M, Moghadam MH. Low level laser therapy (LLLT) combined with physical exercise, a more effective treatment in low back pain. J Laser Med Sci 2012;3:67-0,

16. Tumilty S, Munn J, McDonough S, Hurley DA, Basford JR, Baxter GD. Low level laser treatment of tendinopathy: A systematic review with metaanalysis. Photomed Laser Surg 2010;28:3-16.

17. Bjordal JM, Lopes-Martins RA, Iversen VV. A randomised, placebo controlled trial of low level laser therapy for activated Achilles tendinitis with microdialysis measurement of peritendinous prostaglandin E2 concentrations. Br J Sports Med 2006;40:76-80; discussion 76-80.

18. Bjordal JM, Lopes-Martins RA, Joensen J, Couppe C, Ljunggren AE, Stergioulas $A$, et al. A systematic review with procedural assessments and meta-analysis of low level laser therapy in lateral elbow tendinopathy (tennis elbow). BMC Musculoskelet Disord 2008;9:75.

19. Bjordal JM, Couppé C, Chow RT, Tunér J, Ljunggren EA. A systematic review of low level laser therapy with location-specific doses for pain from chronic joint disorders. Aust J Physiother. 2003;49:107-16.

20. Tascioglu F, Armagan O, Tabak Y, Corapci I, Oner C. Low power laser treatment in patients with knee osteoarthritis. Swiss Med Wkly 2004;134:254-8.

21. Brosseau L, Welch V, Wells G, DeBie R, Gam A, Harman K, et al. Low level laser therapy (Classes I, II and III) for treating osteoarthritis. Cochrane Database Syst Rev 2004;3:CD002046.

22. Stasinopoulos DI, Johnson MI. Effectiveness of low-level laser therapy for lateral elbow tendinopathy. Photomed Laser Surg 2005;23:425-30.

23. Enwemeka CS, Parker JC, Dowdy DS, Harkness EE, Sanford LE, Woodruff LD. The efficacy of low-power lasers in tissue repair and pain control: A meta-analysis study. Photomed Laser Surg 2004;22:323-9.

24. Hopkins JT, McLoda TA, Seegmiller JG, Baxter GD. Low-level laser therapy facilitates superficial wound healing in humans: A triple-blind, sham-controlled study. J Athl Train 2004;39:223-9.

25. Fukuda VO, Fukuda TY, Guimarães M, Shiwa S, de Lima Bdel C, Martins RÁ, et al. Short-term Eefficacy of low-level laser therapy in patients with knee osteoarthritis: A randomized placebo-controlled, double-blind clinical trial. Rev Bras Ortop 2015;46:526-33.

26. Conti PC. Low level laser therapy in the treatment of temporomandibular disorders (TMD): A double-blind pilot study. Cranio 1997;15:144-9.

27. Brosseau L, Robinson V, Wells G, Debie R, Gam A, Harman K, et al. Low level laser therapy (Classes I, II and III) for treating rheumatoid arthritis. Cochrane Database Syst Rev 2005;4:CD002049.

28. Stiglić-Rogoznica N, Stamenković D, Frlan-Vrgoc L, Avancini-Dobrović $V$, Vrbanić TS. Analgesic effect of high intensity laser therapy in knee osteoarthritis. Coll Antropol 2011;35 Suppl 2:183-5.

29. Prochazka M. "Class IV Laser in Noninvasive Laser Therapy." Laser
Partner; $\quad 2006 . \quad$ Available from: https://www.laserpartner.org/lasp/web/en/2003/0069html [Last access date 2006].

30. Bettencourt F. Effects of class IV laser in knee osteoarthritis: $A$ randomized control trial. J Arthritis 2020:9:1-289.

31. Vescovi P, Merigo E, Manfredi M, Meleti M, Fornaini C, Bonanini M, et al. Nd: YAG laser biostimulation in the treatment of bisphosphonateassociated osteonecrosis of the jaw: Clinical experience in 28 cases. Photomed Laser Surg 2008;26:37-46.

32. Santamato A, Solfrizzi V, Panza F, Tondi G, Frisardi V, Leggin BG, et al. Short-term effects of high-intensity laser therapy versus ultrasound therapy in the treatment of people with subacromial impingement syndrome: A randomized clinical trial. Phys Ther 2009;89:643-52.

33. Wyszyńska J, Bal-Bocheńska M. Efficacy of high-intensity laser therapy in treating knee osteoarthritis: A first systematic review. Photomed Laser Surg 2018;36:343-53

34. Graudenz K, Raulin C. Von einsteins quantentheorie zur modernen lasertherapie: Historie des lasers in der dermatologie und ästhetischen medizin. Hautarzt 2003;7:575-82.

35. Kojevnikov A. Nikolay Gennadiyevich Basov. Encyclopedia Britannica; 2021. Available from: https://www.britannica.com/biography/NikolayBasov [Last accessed on 2021 Aug 2].

36. Charles H. Townes Biographical. NobelPrize.org. Nobel Prize Outreach AB 2021. Sun. 31 Oct; 2021. Available from: https://www.nobelprize.org/prizes/physics/1964/townes/biographical [Last accessed on 2021 Aug 2].

37. Schawlow AL. Schawlow Biographical. NobelPrize.org. Nobel Prize Outreach $A B$ 2021. Sun. 31 Oct; 2021. Available from: https://www.nobelprize.org/prizes/physics/1981/schawlow/biographical [Last accessed on 2021 Aug 2].

38. Maiman TH. Stimulated optical radiation in ruby. Nature 1960;187:493-

39. Sommer AP, Pinheiro AL, Mester AR, Franke RP, Whelan HT. Biostimulatory windows in low-intensity laser activation: Lasers, scanners, and NASA's light-emitting diode array system. J Clin Laser Med Surg 2001;19:29-33.

40. Nouri K, Ballard CJ. Laser therapy for acne. Clin Dermatol 2006;24:2632.

41. Evans $D H$, Abrahamse $H$. Efficacy of three different laser wavelengths for in vitro wound healing. Photodermatol Photoimmunol Photomed 2008;24:199-210.

42. Whelan HT, Smits RL Jr., Buchman EV, Whelan NT, Turner SG, Margolis DA, et al. Effect of NASA light-emitting diode irradiation on wound healing. J Clin Laser Med Surg 2001;19:305-14.

43. Peplow PV, Chung TY, Baxter GD. Laser photobiomodulation of wound healing: A review of experimental studies in mouse and rat animal models. Photomed Laser Surg 2010;28:291-325.

44. Conlan MJ, Rapley JW, Cobb CM. Biostimulation of wound healing by low-energy laser irradiation. A review. J Clin Periodontol 1996;23:492-6.

45. Woodruff LD, Bounkeo JM, Brannon WM, Dawes KS, Barham CD, Waddell $D L$, et al. The efficacy of laser therapy in wound repair: A metaanalysis of the literature. Photomed Laser Surg 2004;22:241-7.

46. Dundar U, Turkmen U, Toktas H, Solak O, Ulasli AM. Effect of highintensity laser therapy in the management of myofascial pain syndrome of the trapezius: A double-blind, placebo-controlled study. Lasers Med Sci 2015;30:325-32.

47. Kneebone WJ, Crna DC, DIHom CN. Practical applications of low level laser therapy. Pract Pain Manag 2006;6:34-40.

48. Marshall RP, VIková K. Spectral dependence of laser light on lighttissue interactions and its influence on laser therapy: An experimental study. Insights Biomed 2020;5:1.

49. Baack HO. Comparison of energy spread homogeneity in automated and manual class 4 laser therapy. Res Rev 2020;9:1-9.

50. Khalkhal E, Razzaghi M, Rostami-Nejad M, Rezaei-Tavirani M, Heidari Beigvand $H$, Tavirani MR. Evaluation of laser effects on the human body after laser therapy. J Lasers Med Sci 2020;11:91-7.

51. Tseng SH, Bargo P, Durkin A, Kollias N. Chromophore concentrations, absorption and scattering properties of human skin in-vivo. Opt Express 2009;17:14599-617

52. Chen CH, Tsai JL, Wang YH, Lee CL, Chen JK, Huang MH. Low-level 
laser irradiation promotes cell proliferation and $m R N A$ expression of Type I collagen and decorin in porcine Achilles tendon fibroblasts in vitro. J Orthop Res 2009;27:646-50.

53. Karu TI, Hode L. Ten Lectures on Basic Science of Laser Phototherapy. Grängesberg: Prima Books; 2007.

54. Mester A, Mester A. The history of photobiomodulation: Endre mester (1903-1984). Photomed Laser Surg 2017;35:393-4.

55. Peplow PV, Chung TY, Baxter GD. Laser photobiomodulation of proliferation of cells in culture: $A$ review of human and animal studies. Photomed Laser Surg 2010;28 Suppl 1:S3-40.

56. Karu T. Mitochondrial mechanisms of photobiomodulation in context of new data about multiple roles of ATP. Photomed Laser Surg 2010;28:15960 .

57. Holden PK, Li C, Da Costa V, Sun CH, Bryant SV, Gardiner DM, et al. The effects of laser irradiation of cartilage on chondrocyte gene expression and the collagen matrix. Lasers Surg Med 2009;41:487-91.

58. Chen $\mathrm{CH}$, Hung HS, Hsu SH. Low-energy laser irradiation increases endothelial cell proliferation, migration, and eNOS gene expression possibly via PI3K signal pathway. Lasers Surg Med 2008;40:46-54.

59. Zati A, Desando G, Cavallo C, Buda R, Giannini S, Fortuna D, et al. Treatment of human cartilage defects by means of $\mathrm{Nd}$ : YA G laser therapy. $J$ Biol Regul Homeost Agents 2012;26:701-11.

60. Peat FJ, Colbath AC, Bentsen LM, Goodrich LR, King MR. In vitro effects of high-intensity laser photobiomodulation on equine bone marrowderived mesenchymal stem cell viability and cytokine expression. Photomed Laser Surg 2018;36:83-91.

61. Bjordal JM, Lopes-Martins RA, Joensen J, Iversen VV. The antiinflammatory mechanism of low level laser therapy and its relevance for clinical use in physiotherapy. Phys Ther Rev 2010;15:286-293.

62. Walker J. Relief from chronic pain by low power laser irradiation. Neurosci Lett 1983;43:339-44.

63. Fiore P, Panza F, Cassatella G, Russo A, Frisardi V, Solfrizzi V, et al. Short-term effects of high-intensity laser therapy versus ultrasound therapy in the treatment of low back pain: A randomized controlled trial. Eur J Phys

\section{Rehabil Med 2011;47:367-73.}

64. Bálint G, Barabás K, Zeitler Z, Bakos J, Kékesi KA, Pethes A, et al. Ex vivo soft-laser treatment inhibits the synovial expression of vimentin and $\alpha$ enolase, potential autoantigens in rheumatoid arthritis. Phys Ther 2011;91:665-74

65. Paradiz SG, Guiloff L, Aroca MB. HILT (High Intensity Laser Therapy) HILT and RSWT (Radial Schockwave Treatment): Pain and Pacient Satisfaction Evaluation of 100 Patients. Available from: https://www.shockwavetherapy.org/fileadmin/user upload/dokumente/P DFs/Abstracts/abstracts-ismst-congress-18-meñdoza-2015.pdf [Last accessed on 2021 Aug 2].

66. Coombes BK, Bisset $L$, Vicenzino B. A new integrative model of lateral epicondylalgia. Br J Sports Med 2009;43:252-8

67. Armagan O, Tascioglu F, Ekim A, Oner C. Long-term efficacy of low level laser therapy in women with fibromyalgia: A placebo-controlled study. J Back Musculoskelet Rehabil 2006;19:135-40.

68. Jovicić M, Konstantinović L, Lazović M, Jovicić V. Clinical and functional evaluation of patients with acute low back pain and radiculopathy treated with different energy doses of low level laser therapy. Vojnosanit Pregl 2012;69:656-62.

69. Rochkind S, Geuna S, Shainberg A. Chapter 25: Phototherapy in peripheral nerve injury: Effects on muscle preservation and nerve regeneration. Int Rev Neurobiol 2009;87:445-64.

70. Kawecki M, Bernad-Wiśniewska T, Sakiel S, Nowak M, Andriessen A. Laser in the treatment of hypertrophic burn scars. Int Wound J 2008;5:8797.

71. Marotti J, Sperandio FF, Fregnani ER, Aranha AC, de Freitas PM, de Eduardo CP. High-intensity laser and photodynamic therapy as a treatment for recurrent herpes labialis. Photomed Laser Surg 2010;28:439-44.

72. Kozarev J, Vizintin Z. Novel laser therapy in treatment of onychomycosis. J Laser Health Acad 2010;1:1-8.

73. Hochman LG. Laser treatment of onychomycosis using a novel $0.65-$ millisecond pulsed Nd: YAG 1064-nm laser. J Cosmet Laser Ther 2011:13:2-5

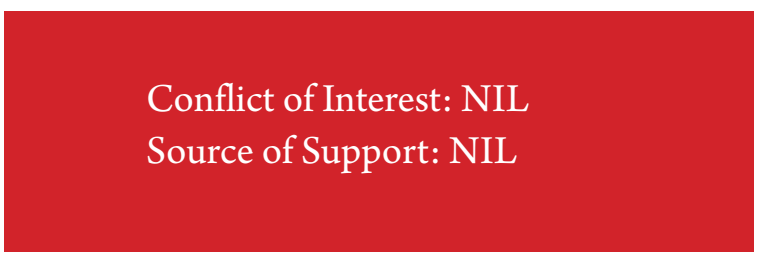

\section{How to Cite this Article}

Guiloff WL, Prouza O, Žarković D | Non Invasive Physical Regenerative Therapies: Laser therapy, Mechanism of Action and Results | Journal of Regenerative Science | December 2021; 1(1):21-25. 